\title{
Analysis of the legal and linguistic typology of human rights texts
}

\section{Feruzakhon YUNUSOVA ${ }^{1}$}

Tashkent State University of Economics

\section{ARTICLE INFO}

\section{Article history:}

Received October 2021

Received in revised form

15 October 2021

Accepted 20 November 2021

Available online

15 December 2021

\footnotetext{
Keywords:

legal translation,

text,

extralinguistic factors,

communication.
}

\section{ABSTRACT}

This article discusses issues based on the analysis of legal texts on human rights. It also analyzes the problems of legal translation and explores the ideas of scientists on this topic. The selection of the characteristic features of a legal text as features of a legal translation is considered. These features are necessary for conducting pre-translation analysis and competent translation by both lawyers and linguists-translators.

2181-1415/C 2021 in Science LLC.

DOI: https://doi.org/10.47689/2181-1415-vol2-iss11/S-pp25-30

This is an open access article under the Attribution 4.0 International (CC BY 4.0) license (https://creativecommons.org/licenses/by/4.0/deed.ru)

\section{Inson huquqlariga oid matnlarning huquqiy va lingvistik tipologiyasini tahlil qilish \\ ANNOTATSIYA}

\section{Kalit so'zlar:}

huquqiy tarjima,

matn,

ekstralingvistik omillar, aloqa.
Ushbu maqolada inson huquqlari bo'yicha matnlarni tahlil qilish asosidagi masalalar ko'rib chiqiladi. Shuningdek, maqolada huquqiy tarjima muammolari tahlil qilingan va bu boradagi olimlarning fikrlari o'rganilgan. Yuridik matnning o'ziga xos xususiyatlarini yuridik tarjimaning o'ziga xos xususiyati sifatida ajratib ko'rsatish ham huquqshunoslar, ham tilshunostarjimonlar tomonidan tarjimadan oldingi tahlil va malakali tarjimani amalga oshirish uchun muhim hisoblanadi.

\footnotetext{
${ }^{1}$ Senior lecturer Department of English language, Tashkent State University of Economics. Tashkent, Uzbekistan.
} 


\section{Анализ юридической и лингвистической типологии текстов по правам человека}

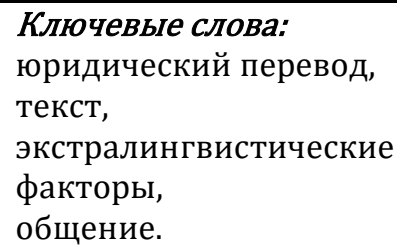

\begin{abstract}
АННОТАЦИЯ
В данной статье рассматриваются вопросы, основанные на анализе юридических текстов по правам человека. Также в ней анализируются проблемы юридического перевода и исследуются идеи ученых по этой теме. Рассмотрено выделение характерных черт юридического текста, как особенностей, юридического перевода. Данные особенности необходимы для проведения предпереводческого анализа и грамотного перевода как юристами, так и лингвистамипереводчиками.
\end{abstract}

Traditionally, typological models of texts that are the subject of scientific and technical translation are considered within the framework of the general theory of translation. Over the past 30 years, there has been a lot of interesting research in the field of applied linguistics, called "language for special purposes" (Language for Special Purposes, LSP). Within the framework of this concept, new typological models of texts were developed, which productively expanded the possibilities of text analysis, and in terms of translation. The exchange of information today is increasing many times over every day, respectively, the number of services for obtaining it increases, but access to this information is complicated by the fact that most of the services are presented in a foreign language. A professionally oriented approach to the study of a foreign language in modern education is relevant not only for s specialties, but also for basic linguistic areas, within which students can acquire additional professional competencies. Legal translation is traditionally studied primarily by lawyers and students of legal specialties, which is understandable due to the fact that legal translation requires deep special knowledge for the interpretation of legal texts and for their adequate transmission into another language. At the same time, recently it has been characterized by a double-edged interest in legal translation both on the part of legal professionals and on the part of translators without legal education. The legal area in some aspects covers all professional areas. Elements of the legal language are found in the texts of contracts, instructions, certificates and other texts of general use that translators have to deal with in their professional activities. Acquaintance with the peculiarities of legal translation is necessary for the competent transfer of elements of a legal text from language to language, which does not violate the existing correspondences between the legal systems of the countries of the source and target languages.

It is known that translation as a multidimensional phenomenon is not only a recoding of semantic-syntactic structures, but also reflects a linguistic vision of the situation, a linguistic picture of the world, embodied in a text that is always distinguished by its national identity [1-3]. Such conditions are usually called extralinguistic factors. Extralinguistic components are of particular importance when translating nationally-labeled vocabulary, which in scientific literature is called non-equivalent or background. The concepts of "lacuna", "cultural reality" are also used. Due to the close interaction of linguistic and non-linguistic factors in the translation process, it is not entirely clear what 
the role of each of them is. This provision determines the relevance of the study. The aim of the work is to systematize and clarify the content of extralinguistic factors. The novelty of the research is the solution to the question of the relationship between linguistic and extra-linguistic factors on the example of the cultural realities of the texts of news agencies, in which the influence of the socio-cultural environment on the translation process is more pronounced than in other types of translation. The solution of the tasks posed requires an appeal to heuristic, descriptive, explanatory, comparative methods of linguistic research. Among the extralinguistic factors, it is customary to include the factor of the author's personality, his worldview, aesthetic preferences, the ideological orientation of the work, emotional tone, imagery, etc. [4]. The attraction of extralinguistic information presupposes knowledge of the subject of communication, which means that the translation procedure cannot be imagined without the involvement of encyclopedic information. Some authors point out that it is necessary to take into account the social orientation of the translation process. So, L.K. Latyshev believes that translation activity is predetermined by a social norm on which the choice of translation strategy depends. The social norm varies, changing in the process of historical development, and reflects the requirements of society for the translator [5].

As well as, extralinguistic factors include the following components: the national originality of the text; the personality of the author of the text and his worldview; encyclopedic information about the subject of communication; social norm of a given historical period, epoch; characteristics of a speech act, such as topic, situation and its participants. Obviously, the selected components describe either subject extra-textual information or pragmatic aspects of the speech situation. In our opinion, some characteristics need to be disclosed in more detail. Indeed, the understanding of cultural reality is based on knowledge of the reality behind words, knowledge of the initial sociocultural system.

The main difficulties in translating legal texts are associated, as a rule, with the interpretation of professional legal terminology. It is the interpretation of the terms and the legal concepts behind them in this particular system of law that is a stumbling block for novice translators. The existing bilingual dictionaries of legal terms cannot solve the problem of translation, since different contexts require knowledge of which translation option to choose in each specific case. Difficulties can be overcome in the course of consultation and even joint work with legal specialists, as well as by referring to a large volume of authentic documents, where the desired terminology is found, to clarify the linguistic environment of the term and its compatibility.

According to T.P. Nekrasov, legal terminology is one of the most difficult and demanded areas in which scientific understanding of the theory and practice of searching for interlanguage correspondences is necessary [10]. In a number of works, we considered the difficulties of translating legal terminology and demonstrated the need for a thorough analysis of the intercultural conformity of legal terms [7]. Agreeing with the opinion of D.N. Shlepnev and Yu.A. Parkhaeva, noting that legal translation is not limited to the translation of terms [5], we will consider other features of the legal text that the translator should pay attention to.

I.S. Alekseeva notes that "the legal text has features of similarity both with the scientific text and with the text of the instruction, since it performs both cognitive and prescriptive functions" [1]. Based on the types of information contained in the legal text, 
I.S. Alekseeva highlights the features of the legal text that are significant for translation [1. PP. 216-219]. We will try to interpret the dominants of legal translation considered by the author, based on the latest research in the field of legal linguistics and linguistics.

The legal text conveys mainly cognitive information. Along with specific standard terms, the legal text contains, according to I.S. Alekseeva, and other ways of transferring cognitive information. Thus, the author notes such a feature of a legal text as tautological cohesion, when the same noun is repeated in each next phrase [1. P. 218], that is, nouns in subsequent uses are not replaced by contextual synonyms. This feature of the legal text, according to the author, is associated with the need for the most transparent transfer of information, with overcoming multiple subjective interpretations. The legal text contains more than cognitive information. I.S. Alekseeva draws attention to the fact that the legal text conveys emotional information, which is contained in legal terms with an archaic connotation. The use in the legal text of terms with an archaic coloration "creates the flavor of a high style ("dismissal from office", "home is inviolable", etc."). According to the author, "the emotional connotation of a legal text is associated with its high status in society and reflects the attitude of people towards it" [1.P.218]. Note here that the emotional connotation of vocabulary is found in standard constructions, in established verbal formulas and cliches. Emotionality in legal text does not extend to syntax. V.B. Isakov writes: "One of the important qualities of the legal language is its emotional neutrality. Even the most extraordinary events and facts from a moral point of view, a lawyer should describe in neutral terms, without exerting emotional pressure and without disclosing his legal assessment. Thus, the legal language differs sharply, for example, from the language of journalism, which, on the contrary, is characterized by the "emotional load" of the dictionary, which initially reveals the position of the author" [5. PP. 65-80].

The listed features of a legal text that convey cognitive and emotional information in a legal text are the dominant systemic features that should be paid attention to in translation. Pre-translation analysis will reveal the presence of these features in each specific text.

The language of law is heterogeneous, it combines several sublanguages: the language of legislation, the language of bylaws, the language of law enforcement practice (also subdivided into several types), the language of legal science, the language of legal education, the language of legal journalism, etc. [5]. So, when analyzing the original text, it seems necessary to determine the subgenre of the legal text; this will determine the choice of the translation strategy for this legal text.

The translation process will also be influenced by the degree of legalization of the legal text. N.D. Golev identifies four degrees of legalization of different types of text [4].

The highest degree of legalization, as the author writes, is created by the most terminologized texts (first of all, the texts of the law, in which "everyday" words from the natural language constitute some undesirable periphery, often considered as an inevitable limitation of the necessary specialization of the legal language).

The average degree is found in texts related to the implementation of the law, for example, in the texts of official correspondence created by professional lawyers. According to N.D. Golev, in such texts, the manifestations of natural language are more regular.

The third degree - in texts created by non-specialists, but with a legal purpose. These texts "reflect the everyday ideas of ordinary native speakers about the legal language (its style and vocabulary) and are often the result of its kind of intuitive imitation". Here "naturalness" can concern not only units of natural language, but also the terms themselves, "which can be very subjectively semanticized". 
The fourth degree - in texts that are created outside the mindset for legal functioning, but got into it for objective reasons, for example, in texts with vocabulary subject to linguistic expertise, in connection with cases of verbal abuse of a person. Here, as N.D. Golev notes, only "points of contact" of such texts with the law are subject to legalization; it is necessary for the "translation" of a natural language into the sphere of the law for its implementation.

The specificity of the translation of legal texts is determined not only by the degree of legalization of the text, but also depends on the category, type of the translated text. Determination of the genre composition of speech works of the legal sphere, as noted by O.P. Sologub, is one of the topical tasks of legal linguistics [6]. Within the genre of legal text, there are many subgenres: contracts, statutes, laws, orders, court decisions, testimonies, examinations, claims, statements, administrative texts (departmental correspondence), educational literature, etc. (classifications of legal texts are widely presented in the work of M.M. Muschinina [9]). Each category of texts is distinguished by its peculiarities, which, if possible, should be preserved in the translation.

The main characteristics of the translation of the legal text will also depend on the type of legal text, its function and addressee. Considering the issues of legal translation by M.M. Muschinina notes that his qualities such as accuracy, comprehensibility and good style can often be mutually exclusive. So, for example, "when translating legal discussions intended to familiarize with certain legal issues of a wide range of readers, clarity and style may be more important than the accuracy of the transmission of information", and "when translating a sentence to be carried out in another country, accuracy is the most important requirement" [9. P. 29].

Texts from different legal fields have their own specificity of translation. MM. Muschinina writes the following about this:

"Difficulties in translation arise more often if the translated text belongs to the area in which the national and regional features of the legal system are more pronounced (for example, procedural law, family law, administrative structure). Conversely, texts from legal areas based on international exchange and cooperation are easier to translate (e.g. commercial law, banking law, consumer protection). The latter can be said about some areas of law, equally developing and emerging in states that are at approximately the same level of socio-economic development (for example, environmental law)" [9. P. 28].

As you can see, when translating a legal text, it is necessary to take into account various linguistic and extralinguistic factors that affect the specifics of legal translation: legal terminology, its interpretation and use; "Tautological cohesion" (term by I.S. Alekseeva), manifested in the impossibility of replacing nouns with contextual synonyms; present tense form in active and passive voice; verbal structures of modality of necessity and modality of possibility; various syntactic structures that unambiguously and unambiguously convey the content; truncated impressiveness of the text; emotional connotation of vocabulary in established verbal formulas and emotional neutrality of syntax; the degree of legalization of the text; type and subgenre of legal text; legal area of functioning of the text.

\section{REFERENCES:}

1. Alekseeva I.S. Professional training of a translator: textbook. 2001.

2. Golev N.D. Statement of problems at the junction of language and law. Barnaul: Altai. University, 1999. - PP. 4-11. 
3. Golev N.D. Legal communication in the mirror of natural language. Barnaul: Altai. University, 2006. - PP. 6-37.

4. Shirobokova L.P. Legal texts: the experience of grammatical and typological research. M., 2007.

5. Shlepnev D.N., Parkhaeva Yu.A. The problem of selection of educational and methodological materials for the course of legal translation. Perm: Publishing house Perm. University, 2008. - PP. 494-511.

6. Barkhudarov L.S. Language and translation. Moscow: International Relations, 1975. - P. 240.

7. Latyshev L.K., Semenov A.L. Translation: Theory, practice and teaching methods. Moscow: Academy, 2005. - P. 192.

8. Smirnitskiy A.I. Lexicology of the English language. Publishing house of Leningrad University, 1963. - P. 208.

9. Muschinina M.M. On legal linguistics in Germany and Austria. Legal aspects of language and linguistic aspects of law. Barnaul: Altai. University, 2004. - PP. 19-32. 